\title{
Using a limited mapping strategy to identify major QTLs for resistance to grapevine powdery mildew (Erysiphe necator) and their use in marker-assisted breeding
}

\author{
S. Riaz • A. C. Tenscher • D. W. Ramming • \\ M. A. Walker
}

Received: 10 May 2010/Accepted: 4 December 2010/Published online: 28 December 2010

(C) The Author(s) 2010. This article is published with open access at Springerlink.com

\begin{abstract}
A limited genetic mapping strategy based on simple sequence repeat (SSR) marker data was used with five grape populations segregating for powdery mildew (Erysiphe necator) resistance in an effort to develop genetic markers from multiple sources and enable the pyramiding of resistance loci. Three populations derived their resistance from Muscadinia rotundifolia 'Magnolia'. The first population (06708) had 97 progeny and was screened with 137 SSR markers from seven chromosomes $(4,7,9,12,13,15$, and 18) that have been reported to be associated with powdery or downy mildew resistance. A genetic map was constructed using the pseudo-testcross strategy and QTL analysis was carried out. Only markers from chromosome 13 and 18 were mapped in the second (04327) and third (06712) populations, which had 47 and 80 progeny, respectively. Significant QTLs for powdery mildew resistance with overlapping genomic regions were identified for different tissue types (leaf, stem, rachis, and berry) on chromosome 18 , which distinguishes the resistance in 'Magnolia' from that present in other accessions of $M$. rotundifolia and controlled by the Runl gene on chromosome 12. The 'Magnolia' resistance locus was termed as
\end{abstract}

Communicated by E. Guiderdoni.

Electronic supplementary material The online version of this article (doi:10.1007/s00122-010-1511-6) contains supplementary material, which is available to authorized users.

S. Riaz · A. C. Tenscher · M. A. Walker $(\square)$

Department of Viticulture and Enology,

University of California, Davis, CA 95616, USA

e-mail: awalker@ucdavis.edu

D. W. Ramming

USDA-Agricultural Research Service,

Parlier, CA 93468, USA
Run2.1. Powdery mildew resistance was also mapped in a fourth population (08391), which had 255 progeny and resistance from $M$. rotundifolia 'Trayshed'. A locus accounting for $50 \%$ of the phenotypic variation mapped to chromosome 18 and was named Run2.2. This locus overlapped the region found in the 'Magnolia'-based populations, but the allele sizes of the flanking markers were different. 'Trayshed' and 'Magnolia' shared at least one allele for $68 \%$ of the tested markers, but alleles of the other $32 \%$ of the markers were not shared indicating that the two $M$. rotundifolia selections were very different. The last population, 08306 with 42 progeny, derived its resistance from a selection Vitis romanetii C166-043. Genetic mapping discovered a major powdery mildew resistance locus termed Ren 4 on chromosome 18, which explained $70 \%$ of the phenotypic variation in the same region of chromosome 18 found in the two $M$. rotundifolia resistant accessions. The mapping results indicate that powdery mildew resistance genes from different backgrounds reside on chromosome 18, and that genetic markers can be used as a powerful tool to pyramid these loci and other powdery mildew resistance loci into a single line.

\section{Introduction}

Grapevine powdery mildew is the most important fungal disease of grapes throughout the world's grape growing regions. The disease is caused by an obligate biotrophic ascomycete, Erysiphe necator (syn. Uncinula necator), and requires living grape tissue for growth and reproduction. Powdery mildew ascospores germinate and develop hyphae, which produce haustoria that penetrate the cuticle and cell wall of the host plant to draw nutrients from epidermal cells. After establishment, mycelial mats form on 
tissue surfaces that produce conidiophores and chains of conidia. The leaves, shoots, rachis, and maturing berries are all susceptible to infection. Infections on the leaves reduce net photosynthesis and retard shoot and berry development. Severe infections weaken grapevines and lead to loss of fruit quality and yield as a result of berry cracking and cluster rot (http://www.ipm.ucdavis.edu/ PMG/r302100311.html). Mildew scars on berries make them unacceptable for the fresh market. Powdery mildew is controlled by the prophylactic application of fungicides to prevent the fungus from establishing. Application intervals can be as short as 7 days depending upon the weather conditions and shoot growth. This is an expensive and laborious task. In California vineyards alone, over 18,000 metric tons of sulfur were applied to control powdery mildew in 2008 (http://www.cdpr.ca.gov/docs). The California Farm Bureau estimates that without the use of fungicide, California grape production would drop by $97 \%$ (http://westrenfarmpress.com/news). E. necator's ability to rapidly develop resistance to commonly used fungicides further hampers efforts to control this disease (Miller and Gubler 2004). In addition to the cost and risk of resistant strains developing, there is increasing public pressure to reduce pesticide use due to environmental and human health concerns.

Given these biological, economic and environmental concerns, grape breeders have been attempting to develop powdery mildew resistant cultivars with high quality fruit for many years. However, the successful introgression of resistance into existing cultivars via conventional breeding is time consuming and expensive. It can take 10-20 years to develop a new variety with favorable fruit characteristics for table or raisin grape use and longer to incorporate the traits required for good wine quality. It is also extremely difficult to pyramid resistance from different genetic backgrounds into a single line by conventional breeding alone because resistant plants can be phenotyped by greenhouse or field tests, but can only be genotyped if molecular markers are available. Molecular genetic techniques can greatly aid breeders by providing information on the genetics of resistance and by allowing the identification of genomic regions that carry resistance genes from different genetic backgrounds. Thus, enabling the introgression of resistance genes into elite lines via markerassisted selection (MAS), and the use of MAS to pyramid resistance genes to increase the durability of resistance in the field.

Sources of disease resistance are normally found in geographic regions where populations of the pathogen and host plant co-evolve. Powdery mildew and downy mildew (Plasmopara viticola), another equally serious mildew disease of grape common in warm moist summer climates, are thought to have originated in the eastern and central
United States and were imported to Europe by the middle of nineteenth century. Within a short period of time, they spread throughout Europe and the Mediterranean region. Many North American Vitis species are known to have high levels of resistance to both of these mildew diseases (Olmo 1986; Eibach et al. 1989; Staudt 1997). Although powdery and downy mildew are not reported to exist in Asia, several Chinese Vitis species have resistance to both fungi (Wan et al. 2007). This is an unusual situation, given that the Chinese Vitis and the two fungi did not co-evolve. It is possible that other fungal diseases in China may have induced a broad resistance to mildew diseases. Two other species of downy mildew (Plasmopara cissii, and Plasmopara amurensis) exist in China and Chinese Vitaceae may have co-evolved with them (Dick 2002). Although the mechanism of resistance to these Plasmopara species is unknown, it may also provide resistance to $P$. viticola and E. necator.

The genetic basis of powdery and downy mildew resistance has been evaluated and mapped in several genetic backgrounds including hybrids developed from North American Vitis species, two Muscadinia rotundifolia accessions (G52 and 'Dearing'), and two Near Eastern $V$. vinifera cultivars 'Kishmish vatkana' and 'Dzhandzhal kara' (Pauquet et al. 2001; Dalbo et al. 2001; Merdinoglu et al. 2003; Fischer et al. 2004; Akkurt et al. 2006; Hoffmann et al. 2008; Welter et al. 2007; Marguerit et al. 2009; Bellin et al. 2009; Coleman et al. 2009). Several Chinese Vitis species (V. amurensis, V. romanetii, V. piasezkii, $V$. davidii, and $V$. liubanensis) have also attracted attention as new sources of powdery mildew resistance for use in breeding efforts (Wan et al. 2007). Most of the Chinese Vitis species have an advantage over the North American Vitis species in that their fruit flavors are more neutral, while still being fully inter-fertile with $V$. vinifera. However, a thorough understanding of the inheritance, genetic control, and mechanisms of resistance to powdery mildew is required before these resistance sources can be optimally combined.

Studying the genetics of pathogen resistance requires establishment and phenotyping of breeding/mapping populations, fine-tuning of evaluation techniques, development of genetic maps to enable the identification of genomic regions associated with traits of interest, and identification of genetic markers that can be used for MAS and pyramiding resistance from different backgrounds. Over the past 10 years a tremendous amount of molecular genetic information has become available to the grape research community and has enabled molecular breeding for pest and pathogen resistance. Genetic maps based on readily transferable molecular markers are available from a range of Vitis species backgrounds enabling the identification of genomic regions associated with resistance to fungi, 
bacteria, nematodes, and horticultural traits (Pauquet et al. 2001; Fischer et al. 2004; Barker et al. 2005; Riaz et al. 2006; Cabezas et al. 2006; Hoffman et al. 2008; Mejía et al. 2007; Walker et al. 2007; Welter et al. 2007; Xu et al. 2008). The completed grape genome sequence and availability of several physical maps have allowed the search for genes encoding for proteins containing both nucleotide binding sites (NBS) and leucine rich repeats (LRR) domains; sequences often associated with disease resistance (Jaillon et al. 2007; Velasco et al. 2007; Moroldo et al. 2008). The comparative analysis of grape disease resistance genes to other woody species has further enabled the identification of chromosomal regions that carry resistance genes. Yang et al. (2008) reported that in grapes, NBS- encoding resistance (R-genes) are predominantly clustered on chromosome 4, 5, 7, 9, 12, 13, 15, and 18. In an earlier study, Di Gaspero et al. (2007) reported on the genetic mapping of resistance gene analog (RGA) markers and found the majority of them were clustered on chromosome 9, 12, 13, 18, and 19. In addition, several RGA clusters mapped to chromosomal regions where genetic resistance to powdery and downy mildew had been mapped (Pauquet et al. 2001; Merdinoglu et al. 2003; Fischer et al. 2004; Akkurt et al. 2006; Welter et al. 2007; Hoffmann et al. 2008; Marguerit et al. 2009; Bellin et al. 2009; Coleman et al. 2009). Interestingly, the Runl (resistance to $U$. necator 1 ) and Rpvl (resistance to P. viticola 1) loci cosegregate on chromosome 12. Sequencing of this region identified a cluster of RGAs encoding TIR-NBS-LRR type resistance proteins (Barker et al. 2005). So far, the screening of over 5,000 backcross progeny has not revealed a single recombination event between Runl and Rpv1, which suggests that resistance to both mildews is either encoded by the same resistance gene or different members of the same resistance gene cluster (Dry et al. 2009).

Identification and localization of powdery and downy mildew resistance loci from different backgrounds are a valuable information that grape breeders can utilize to exploit alternative powdery mildew resistance resources in a more efficient manner and may not require genetic mapping of all 19 grape chromosomes. To date major loci as well as major and minor QTLs for both powdery and downy mildew resistances from a broad range of Vitis species have been genetically mapped to chromosome 4, 7, $9,12,13,15$, and 18. These chromosomes also carry the majority of the RGA-like genes present in grape (Di Gaspero et al. 2007; Yang et al. 2008). Co-localization of powdery and downy mildew resistance genes on chromosome 12 (Dry et al. 2009) further points to the potential of identifying powdery mildew resistance in similar genomic region from other backgrounds. Grape breeders could utilize a "limited mapping strategy" by first generating framework maps with simple sequence repeat markers
(SSR) from chromosomes that are reported to be associated with powdery and downy mildew resistance, and then associating these genomic regions with disease evaluation data from relatively small sized populations. Statistical analysis, genetic mapping and QTL analysis can be performed on these limited sets of data. If a major resistance locus exists on these chromosomes, then SSR marker alleles that are linked to resistance can be identified and used to pyramid resistance from different genetic backgrounds; thereby, introgressing potentially different forms or mechanisms of resistance. Meanwhile, identification of QTLs with smaller effects would direct breeders to increase the size of mapping populations and obtain highresolution maps of all the chromosomes to identify other genomic regions contributing to resistance.

In this study, a limited mapping strategy was used to effectively identify a major powdery mildew resistance locus in a $F_{1}$ population with resistance inherited from the Chinese species $V$. romanetii. Major QTLs for powdery mildew resistance were identified from $\mathrm{BC}_{1}, \mathrm{BC}_{2}$, and $\mathrm{BC}_{3}$ populations, where resistance was inherited from two different $M$. rotundifolia cultivars 'Magnolia' and 'Trayshed'. QTL analysis was based on phenotypic ratings obtained from natural infections of field-grown plants under high powdery mildew pressure. All plant parts where possible (leaf, cane, cluster rachis, and berries) were evaluated for symptoms of powdery mildew infection. The results for the varying forms of resistance detected in the two M. rotundifolia cultivars, and methods to effectively pyramid genomic regions associated with powdery mildew resistance for breeding will be presented.

\section{Materials and methods}

\section{Plant material}

The segregation of resistance to powdery mildew was studied in five populations with varying numbers of progeny. Details of these populations and their pedigrees are provided in Table 1 and Supplementary Table 1. The populations and their resistant and susceptible parents are maintained at the Department of Viticulture and Enology, University of California, Davis, CA.

Three populations derived their resistance from JB81107-11. The 04327 (47 seedlings) and 06708 (97 seedlings) populations were crosses of JB81-107-11 and the susceptible $V$. vinifera cultivars 'Tokay' and 'Chenin Blanc', respectively. The 04327 population was created in 2004 as a small population to evaluate JB81-107-11's powdery mildew resistance before larger populations were created. This population was screened in the field in 2005 and the results indicated that JB81-107-11 was a promising source 
Table 1 Details of pedigree of resistant lines, susceptible parent, population size and tissues evaluated to map powdery mildew resistance

\begin{tabular}{|c|c|c|c|c|c|}
\hline $\begin{array}{l}\text { Population } \\
\text { code }\end{array}$ & Resistant female parent & $\begin{array}{l}\text { Susceptible } \\
\text { male parent }\end{array}$ & $\begin{array}{l}\text { Number of } \\
\text { seedlings }\end{array}$ & $\begin{array}{l}\text { Tissue } \\
\text { evaluated }\end{array}$ & $\begin{array}{l}\text { Year of } \\
\text { evaluation }\end{array}$ \\
\hline 06708 & $\begin{array}{l}\text { JB81-107-11 }\{\text { NC74C049-10 [UC Davis e4-12 } \\
\text { \{UCD Y14-14< T6-31(F2-35 × Trayshed) x OP > x } \\
\text { Grenache }\} \text { x M. rotundifolia Magnolia] x Verdelet }\}\end{array}$ & Chenin Blanc & 97 & $\begin{array}{l}\text { Leaf, cane, } \\
\text { rachis, fruit }\end{array}$ & 2009 \\
\hline 04327 & JB81-107-11 & Tokay & 47 & $\begin{array}{l}\text { Leaf, cane, } \\
\text { rachis, fruit }\end{array}$ & 2009 \\
\hline 06712 & A90-71 (JB81-107-11 × A61-52) & Flame seedless & 80 & $\begin{array}{l}\text { Leaf, cane, } \\
\text { rachis, fruit }\end{array}$ & 2009 \\
\hline 08391 & $\begin{array}{l}\text { e2-9 [UCD Y14-14< T6-31 }(\text { F2-35 } \times \text { Trayshed }) x \\
\text { OP }>\text { x Palomino] }\end{array}$ & Malaga Rosada & 255 & Leaf & 2009 \\
\hline 08306 & C166-043 (V. romanetii-DVIT2732) & $\begin{array}{l}\text { F8909-08 } \\
\quad \text { V. rupestris } \mathrm{x} \\
\text { V. arizonica) }\end{array}$ & 42 & Leaf, cane & 2009 \\
\hline
\end{tabular}

of resistance. JB81-107-11 has a complex pedigree with two $M$. rotundifolia cultivars, 'Trayshed' and 'Magnolia', as well as 'Verdelet', a complex hybrid created from North American Vitis species (Supplementary Table 1). The morphological characteristics of JB81-107-11 are typical of vinifera-rotundifolia (VR) hybrids, and it did not had powdery mildew symptoms here in California. In addition to the 06708 population, the 06712 population (80 seedlings) was also created in 2006. It was a cross of the $\mathrm{BC}_{2}$ selection $\mathrm{A} 90-71$ by the susceptible $V$. vinifera 'Flame Seedless'. The cluster shape of A90-71 is similar to its resistant parent, JB81-107-11, but its leaves, berry shape, size, and color are more $V$. vinifera-like. No active powdery mildew was found on any plant parts, although occasional "oil spotting" of the leaves, where powdery mildew infection was initiated and then suppressed, was observed. A90-71 is fruitful with good seed germination. The 06712 population provided us with an opportunity to verify potential QTLs for powdery mildew resistance in a $\mathrm{BC}_{3}$ generation. Both the 04327 and 06712 populations were evaluated for disease symptoms in the field as well as with markers from the chromosomes found to be associated with powdery mildew resistance after analysis of the 06708 population (Table 1).

The 08391 population was a cross of the powdery mildew resistant $\mathrm{BC}_{2}$ selection e2-9 and the susceptible $V$. vinifera 'Malaga Rosada', which produced a $\mathrm{BC}_{3}$ population containing $93.75 \% \mathrm{~V}$. vinifera (Table 1). The resistant selection e2-9 does not show any symptoms of powdery mildew. e2-9 was developed by Olmo at UC Davis using resistance from $M$. rotundifolia 'Trayshed'. We utilized two SSR markers (VMC4f3.1 and VMC8g9), previously shown to flank the powdery mildew resistance locus Runl (Barker et al. 2005), in conjunction with field evaluation data from the $\mathrm{BC}_{1}$, and $\mathrm{BC}_{2}$ populations to identify the alleles in coupling with resistance from 'Trayshed' on chromosome 12 (manuscript in preparation).
'Trayshed' has a unique and different allelic profile for the markers that flank the Runl locus identified from NC6-15. The selection NC6-15 inherited its resistance from G52, a cross between the $M$. rotundifolia cultivars 'Thomas' and 'Hope' (Table 2). The highly resistant selection e2-9 did not inherit the resistance alleles that 'Trayshed' possesses on chromosome 12 , which prompted a search for additional resistance loci, and a test of their utility in powdery mildew resistance breeding. A total of 324 seedlings from the 08391 population were planted in the field for use in map construction, only 255 survived and they were evaluated for powdery mildew resistance and used for QTL analysis.

The 08306 population inherited its powdery mildew resistance from the Chinese species Vitis romanetii accession C166-043 (DVIT 2732). V. romanetii has relatively stiff and long trichomes on its stems, petioles and veins, and cordate un-lobed leaves. C166-043 is a pistillate vine that flowers early, has neutral flavored fruit, and hybridizes easily with other Vitis species making it an excellent parent for powdery mildew resistance breeding. The susceptible male parent was F8909-08, a Pierce's disease-resistant selection that has been used in other studies (Riaz et al. 2009) and shows symptoms of powdery mildew on leaves, stems, and rachis. A total of 42 seedlings were evaluated for disease symptoms and used for map construction (Table 1).

\section{Disease evaluation}

The seedling populations were evaluated under natural infection conditions. Seedlings were planted on their own roots at a spacing of $0.9 \mathrm{~m}$ between the plants and $3.6 \mathrm{~m}$ between the rows. The seedlings were numbered consecutively and resistant and susceptible plants were randomly interspersed. All susceptible plants showed intense powdery mildew infection indicating that powdery mildew was distributed evenly throughout the experimental plot. In 
Table 2 Allelic profile of markers linked to Run1, Run2.1, Run2.2 and Ren4 powdery mildew resistant loci

\begin{tabular}{|c|c|c|c|c|c|c|c|c|c|c|}
\hline \multirow{2}{*}{ a) } & \multirow{2}{*}{$\begin{array}{l}\text { Cultivar name } \\
\text { NC6-15 }\end{array}$} & \multirow{2}{*}{$\begin{array}{l}\text { Reported parentage } \\
\text { Malaga seedling } \# 1 \times M . \text { rotundifolia } \text { G52 (Thomas } \times \text { Hope })\end{array}$} & \multicolumn{2}{|c|}{ VMC4f3.1 } & \multicolumn{2}{|c|}{ VMC8g9 } & \multicolumn{2}{|c|}{ VMC7f2 } & \multicolumn{2}{|c|}{ UDV108 } \\
\hline & & & 188 & 192 & 159 & 176 & - & - & - & - \\
\hline & Thomas & M. rotundifolia & 192 & 202 & 137 & 159 & 193 & 193 & 208 & 208 \\
\hline & Scuppernong & M. rotundifolia & 222 & 222 & 138 & 140 & 193 & 195 & 202 & 220 \\
\hline & Tarheel & [Luola x (Eden x V23R4B2)] & 192 & 202 & 138 & 140 & 193 & 193 & 206 & 206 \\
\hline & Topsail & Latham x Burgaw & 208 & 222 & 138 & 140 & 193 & 195 & 202 & 220 \\
\hline & Magnolia & (Thomas x Scuppernong) x (Topsail x Tarheel) & 208 & 222 & 138 & 140 & 193 & 193 & 202 & 202 \\
\hline & Verdelet & Supplementary Table 1 & 178 & 188 & 164 & 176 & 199 & 199 & 214 & 224 \\
\hline & JB81-107-11 & Supplementary Table 1 & 178 & 208 & 140 & 176 & 193 & 199 & 202 & 224 \\
\hline & A90-71 & Supplementary Table 1 & 192 & 208 & 140 & 164 & 193 & 199 & 202 & 210 \\
\hline \multirow[t]{5}{*}{ b) } & Trayshed & M. rotundifolia, parents unknown & 182 & 192 & 137 & 138 & 195 & 195 & 220 & 220 \\
\hline & e2-9 & Supplementary Table 1 & 186 & 205 & 159 & 164 & 195 & 199 & 220 & 240 \\
\hline & Malaga Rosada & V. vinifera & - & - & - & - & 197 & 199 & 210 & 248 \\
\hline & Palomino & V. vinifera & 174 & 205 & 159 & 170 & - & - & - & - \\
\hline & $\mathrm{F} 2-35$ & V. vinifera & 172 & 186 & 164 & 173 & - & - & - & - \\
\hline \multirow[t]{2}{*}{ c) } & C166-043 & Supplementary Table 1 & 162 & 168 & 170 & 172 & 197 & 199 & 198 & 240 \\
\hline & F8909-08 & Supplementary Table 1 & 174 & Null & 172 & 192 & 203 & 203 & 206 & 240 \\
\hline
\end{tabular}

Alleles that are in coupling to the resistant parents/grandparents are in bold. Alleles that are linked to the resistance are italicized. NC6-15 has been used previously to map the Run1 locus. Based on the comparison of field evaluation data to alleles of linked markers, accession JB81-10711 has inherited its resistance from Magnolia, and not from Verdelet

addition, the experimental area was surrounded by other breeding populations and was not sprayed with fungicides to increase the powdery mildew pressure and infection rate. Plants were irrigated and fertilized to promote vigorous growth, which further intensified the likelihood of mildew infection.

Powdery mildew symptoms were evaluated based on the extent of infection following the Organisation Internationale de la Vigne et du Vin (OIV 1984) and scored 0 (no disease symptoms), 1 (OIV 9) with tiny one or two spots, 2 (OIV 7) limited patches of powdery mildew infection, 3 (OIV 5) patches of infection that are bigger than $5 \mathrm{~cm}$ in diameter, 4 (OIV 3) vast numbers of powdery mildew infection spots and abundant mycelium growth, and 5 (OIV 1) where leaves and other tissue types are covered with unlimited patches of powdery mildew infection. Two people examined each plant and a consensus score was recorded for each plant and tissue type. All plant parts including leaves, canes, and the rachis and berries (when possible), were examined for disease symptoms during September 2009 when powdery mildew pressure was very high and susceptible plants were showing severe symptoms. The presence of powdery mildew scaring on the canes of progeny from the 06708 population was recorded in December 2009 in addition to the September scoring, and both data sets were used for QTL analysis. The 04327 population was evaluated in 2006 for powdery mildew symptoms on all plant parts, and for leaf and cane symptoms in 2005 (Table 1).
DNA extractions, choice of molecular markers and genotyping

Young leaves were obtained from greenhouse-grown seedlings and field-grown plants. DNA was extracted with a modified CTAB procedure as described by Lodhi et al. (1994) with the exclusion of the RNAase step and with DNA precipitation carried out after one cycle of chloroform-isoamyl alcohol.

A total of 137 SSR markers evenly distributed on chromosomes 4, 7, 9, 12, 13, 15, and 18 were selected and tested on a small set of the parents and progeny of the 06708, 08391, and 08306 populations. These three populations represented the three different genetic backgrounds. The primer sequences have been reported in the following studies or sources: The VMC series was developed by the Vitis Microsatellite Consortium; the VVI series is described in Merdinoglu et al. (2005); the UDV primer series is reported in Di Gaspero et al. (2005), the sequences of the VMC, VVI, and UDV primers are available in the NCBI database uni-STS (http://www.ncbi.nlm.nih.gov/); the ctg primer sequences were obtained from the EST-SSR database developed at the University of California, Davis (http://cgf.ucdavis.edu/), the VChr series primers were developed by Cipriani et al. (2008). The protocols described by Riaz et al. (2004) were used to amplify and run the DNA samples on denaturing polyacrylamide gels. The PCR amplifications were performed in $10 \mu \mathrm{l}$ reactions consisting of $10 \mathrm{ng}$ template DNA, 5 pmol of each primer, 
$2.5 \mathrm{mM}$ of each NTP, $1 \mu \mathrm{l} 10 \times$ gold PCR buffer (Perkin Elmer), 0.05 unit AmpliTaq Gold DNA polymerase (Perkin Elmer) and $2 \mathrm{mM} \mathrm{MgCl}_{2}$ solution. All SSR markers were amplified either at a $56^{\circ} \mathrm{C}$ or $52^{\circ} \mathrm{C}$ annealing temperature, keeping all other conditions of the protocol constant: $10 \mathrm{~min}$ at $95^{\circ} \mathrm{C} ; 35$ cycles of $45 \mathrm{~s}$ at $92^{\circ} \mathrm{C}, 45 \mathrm{~s}$ at $56^{\circ} \mathrm{C}$ or $52^{\circ} \mathrm{C}, 1 \mathrm{~min}$ at $72^{\circ} \mathrm{C}$; with a final extension of $10 \mathrm{~min}$ at $72^{\circ} \mathrm{C}$. All amplifications of the parental and population subset were confirmed by running $3 \mu \mathrm{l}$ of the PCR reaction product on $1.5 \%$ agarose gels. Amplification products were separated on denaturing $5 \%$ polyacrylamide sequencing gels and visualized by silver staining with a commercial kit (Promega, Madison, Wisconsin, USA). All gels were scanned and stored in a digital archive.

Only informative polymorphic markers were used on the entire 06708 mapping population. Scoring for each marker was double checked, and any ambiguous genotypes were rerun, or scored as missing data. After preliminary mapping and QTL analysis on the 06708 population, SSR markers from chromosomes 12, 13, and 18 that were determined to have candidates for powdery mildew resistance loci were mapped on the 04327 and 06712 populations. Next, SSR markers that were linked to and flanked the powdery mildew resistance loci from all three populations were repeated to verify scoring and to fill any data gaps. Then all markers from chromosome 12, 13, and 18 that were informative for the parents of the 08306 population were mapped on its 42 progeny. Preliminary QTL analysis indicated a strong resistance locus for chromosome 18 only. Thus, chromosome 18 was targeted for the 08391 population given the mapping results for the 08306 , 06708, 06327, and 06712 populations. In addition, mapping on chromosome 12 would have been less informative for the 08391 population because results showed that the resistant parent e2-9 did not inherit alleles of SSR markers coupled to the resistance locus Run1.2 on chromosome 12 .

\section{Map construction}

Polymorphic markers for each population were scored for each parent where possible, and two data sets were generated that contained the meiotic segregation information from each parent. All markers were evaluated by the Chisquare method to detect gametic segregation distortion from a Mendelian 1:1 ratio $(P \leq 0.05)$. Linkage analysis was performed with JoinMap 4.0 utilizing the double pseudotestcross strategy with a LOD threshold of 5.0, except with the 06708 population where a LOD threshold of 6.0 was used to separate the markers on chromosome 13 and 15 . The best marker order was calculated with the regression mapping algorithm and marker order was retained from the first round only. Map units in centimorgans (cM) were derived from the Kosambi mapping function (Kosambi 1944).
QTL and statistical analysis

Many traits of economic importance are complex, but are scored as discrete classes or categories. They do not show continuous variation, but are still treated as quantitative traits (Falconer and Mackay, 1996). Simple interval mapping (SIM) handles the analysis of ordinal or discrete phenotypic categories. In this study, QTL analysis on the parental linkage maps was performed using two different methods. First, the non-parametric Kruskal-Wallis (KW) rank sum test, designed for categorical data, was applied to the global segregation of each locus and then, SIM was used (Lander and Botstein 1989). A stringency significance level of $P=0.005$ was used for the KW test. Both methods were run using MapQTL 4.0 (Van Ooijen et al. 2002). The LOD threshold for significant QTLs was calculated at $\alpha=5 \%$ for the linkage groups through 1,000 permutations. A maximum LOD value was retained for a QTL position with $a \pm 1$ LOD interval for the confidence interval. A QTL was considered significant only when it was detected by both methods.

The ordinal logistic regression model platform of JMP (8.0) (SAS Institute Inc, North Carolina, USA) was used to estimate the significance of different measured phenotypic traits in association to the chromosomes involved as well as interactions among different chromosomes. The analysis was only run using genotypes with complete marker and phenotypic data. Models were run for each phenotypic trait and for each population. The distribution of traits was calculated for all five populations.

\section{Results}

Marker polymorphism and map construction

A total of 137 markers from seven chromosomes were tested on the small set of the two $M$. rotundifolia cultivars, 'Trayshed' and 'Magnolia', resistant and susceptible parents and four progeny from the 06708 population. Eightyseven SSR markers were polymorphic for the resistant parent JB81-107-11 and were used for the genotyping of the whole population. For each marker, the JB81-107-11 allele that was inherited from 'Magnolia' was scored as ' 1 ' and the allele coming from the $V$. vinifera parent was scored as ' 0 '. This system allowed the marker phase to be kept constant in different generations. JB81-107-11 had normal inheritance for the 'Magnolia' alleles except for three markers on chromosome 7 (VVMD31, VVMD7 and VMC5h5), where no allele of 'Magnolia' was passed on. Thirty-five markers (40\%) showed significant segregation distortion (Supplementary Table 2). The majority of the distorted markers were from chromosome 7, 13, and 15. 
The distortion was caused by an excess presence of alleles inherited from the male parent for chromosome 13 and fewer than expected alleles inherited from the male parent for markers on chromosome 15. Fragmentation of chromosome 7, 9, 13, and 18 was also observed. Marker order was consistent for all chromosomes except 7 and 13, where marker order was not comparable to other available maps (Doligez et al. 2006). Across the seven chromosomes, the mapped marker number varied from 4 to 22 and a total map length of $385 \mathrm{cM}$ was obtained. 'Trayshed' and 'Magnolia' were also compared with 87 SSR markers. For 59 markers (68\%) 'Trayshed' and 'Magnolia' had at least one common allele and for 28 (32\%) markers they did not share an allele confirming their genetic divergence. For the two populations from the JB81-107-11 background, 04327 and 06712, 15 and 13 heterozygous markers, respectively, from chromosome 13 and 18 were used to genotype the progeny plants.

Sixty-five previously mapped markers from chromosome 12,13 , and 18 were tested on the parents and a small set of progeny from the 08306 population (Table 1). All of the tested markers amplified cleanly for C166-043 (V. romanetii), but only 28 were polymorphic and these were used to genotype the progeny. Twenty-two of the polymorphic markers were mapped to chromosome 12 (9 markers over $31 \mathrm{cM}$ ), LG13 (6 markers over $22 \mathrm{cM}$ ), and to a fragmented chromosome 18 (7 markers over $39 \mathrm{cM})$.

Nine markers from chromosome 18 were used to genotype the entire set of 324 progeny from the 08391 population (Table 1). However, only 255 genotypes were used for QTL analysis; the remaining plants died or were too small to evaluate. The marker order for chromosome 12,13 , and 18 in the 08306 population and for chromosome 18 in the 08391 population was consistent with other published $V$. vinifera maps.

Trait analysis

Plant responses to powdery mildew infection were distributed across all five symptom classes in the three populations with 'Magnolia'-based resistance from JB81107-11 (Table 2; Fig. 1a-c). In two of the $\mathrm{BC}_{2}$ populations (06708 and 04327), the resistance level ranged from category 0 , no powdery mildew on any given plant part, to category 5, highly susceptible. The distribution of the genotypes was skewed toward 0 , and symptoms on leaf, cane, rachis, and berry were independent of each other suggesting that different genes may control these traits. There were genotypes without powdery mildew symptoms on leaves, but cane, rachis, and berry scores were in category 3 or above. Similarly, there were genotypes with no symptoms on berries (although these berries may have ripened too early to be attacked), but with obvious
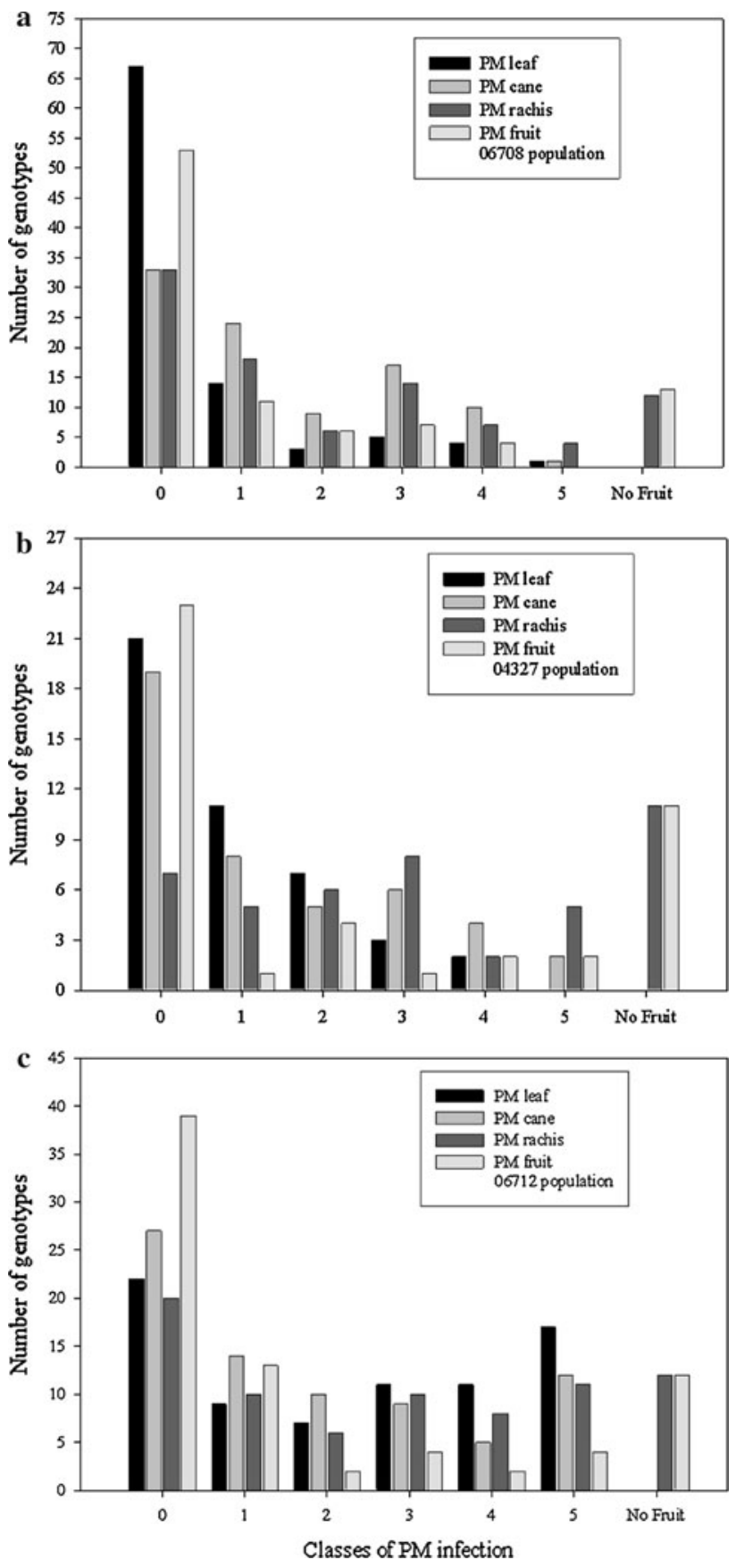

Fig. 1 Distribution of powdery mildew symptoms observed on different tissue types in three grape populations with resistance derived from JB81-107-11. a and b describes the distribution of different powdery mildew classes in the 06708 and 04327 populations, respectively. $\mathbf{c}$ details the distribution of these symptom classes in the 06712 population. Symptoms were classified as $5=$ severe and $0=$ no symptoms

symptoms on leaves, stems, and rachis. The susceptible parents for all three populations had a ranking of 5 with symptoms on all plant parts. A90-71, the resistant parent of the 06712 population, never had symptoms on the rachis, but many of its progeny had active powdery mildew 

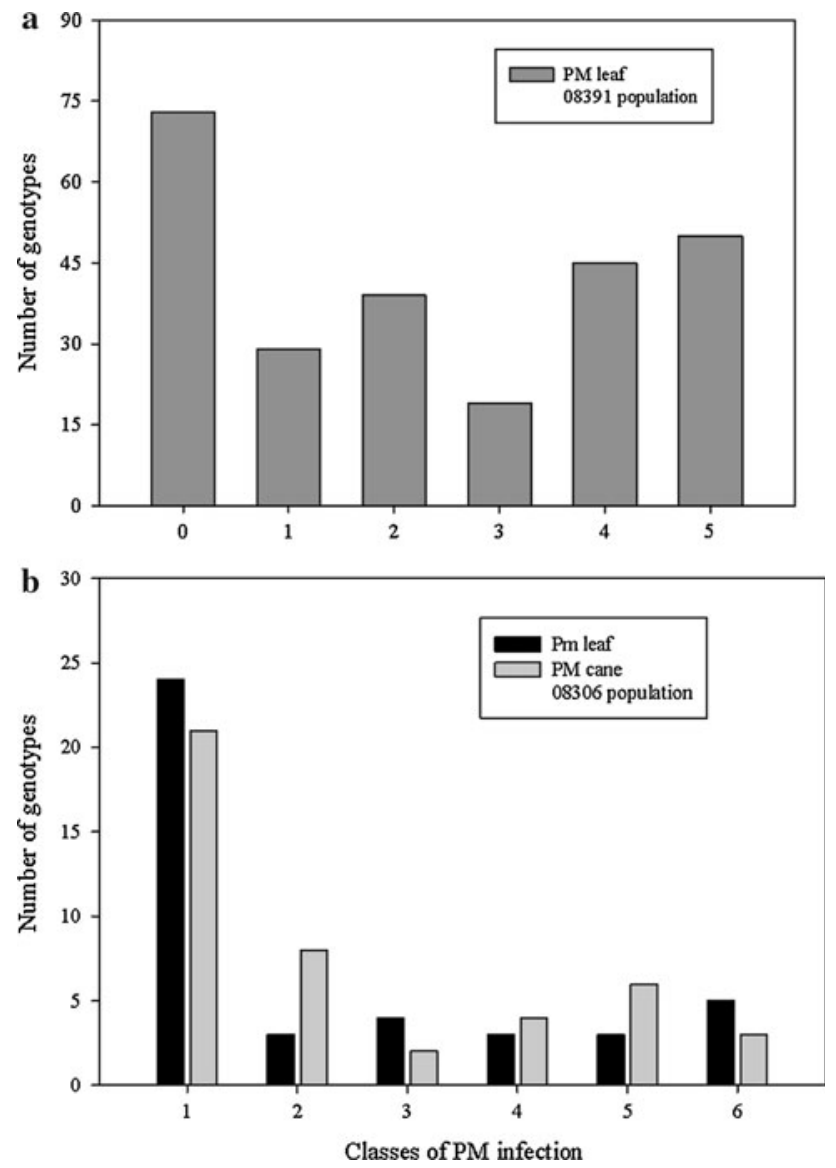

Fig. 2 Distribution of powdery mildew symptoms observed on different tissue types in two grape populations with resistance derived from $M$. rotundifolia Trayshed (08391) and V. romanetii (08306). Symptoms were classified as $5=$ severe and $0=$ no symptoms

growing on the rachis. The rachis was the most susceptible tissue in the next backcross generation from A90-71. Susceptible plants from the 06712 population had more severe symptoms than susceptible plants from the 06708 and 04327 populations. Active powdery mildew was observed on different tissues of the 06708 and 04327 progeny, but symptoms were more common on canes and leaves, and rare on berries.

Only the leaves of the 08391 population were evaluated for powdery mildew symptoms. Most of the susceptible genotypes had symptoms in category $2-5$, or had category 1 symptoms with small darkened spots or oil spot symptoms in which mildew development was arrested shortly after beginning. Resistant plants did not have symptoms on their leaves or stems. The symptom classifications were skewed toward susceptibility (Fig. 2a). Only 73 out of 255 tested seedlings were scored as 0 , without symptoms.

Both stem and leaf symptoms were evaluated in the 08306 population. Most of the symptoms were on the underside of the leaves and to a lesser degree on the upper surface. The susceptible genotypes in this population were often severely infected so that plant growth was dramatically impacted and some genotypes died. The dying plants had stem scores in category 4 and 5. No oil spotting was observed on infected leaves. Although there were only 42 progeny in this population, half of the progeny had no symptoms, while the others spread across the other symptom categories, suggesting that $V$. romanetii possesses a major resistance locus that controls resistance to powdery mildew (Fig. 2b).

QTL analysis

Significant QTLs for powdery mildew resistance on the leaf, stem, rachis and berries were identified using both the Kruskal-Wallis and the SIM analysis for only the resistant parents (Tables 3,4). There was no association between a genomic region and any marker for resistance for the susceptible parents of the five populations. Three populations with resistance from JB81-107-11 (06708, 04327, and 06712) were used for QTL analysis. The $\mathrm{BC}_{2}$ populations, 06708 and 04327 , had suppressed symptoms on leaves, but no QTL was identified for leaf-based resistance. There were QTLs for stem and rachis resistance identified in the 06708 population, which explained 20.4 and $27.4 \%$, respectively, of the phenotypic variation, and they were located in the same genomic region of chromosome 18 . The 04327 population consisted of only 47 progeny, but this was enough to identify QTLs for resistance on the rachis and berries that explained 19.6 and $31.3 \%$ phenotypic variation, respectively. QTL analysis was also carried out after combining both populations, and QTLs for resistance on the stem, rachis, and fruit tissue were observed for the same genomic region (data not presented). No other marker or genomic region from the six additional chromosomes $(4,7,9,12,13$, and 15) showed any association with resistance for any tissue type in the 06708 population. The SSR markers VMC7f2 and VMCNg1e3 were associated to QTLs for stem, rachis, and berry resistance (Suppl. Fig. 1). The markers flanking VMC7f2 were UDV108 and VMC6f11, which were 16.0 and $10.1 \mathrm{cM}$ from the resistance QTL.

To develop more markers to reduce the distance between these flanking markers, the $8 \times$ genome sequence of PN40024 was utilized (http://www.genoscope.cns. fr/externe/GenomeBrowser/Vitis/). The clone sequence of VMC7f2 matches to scaffold 24 on chromosome 18 at position 18,298,920-18,299,199. About $800 \mathrm{~Kb}$ down stream from VMC7f2's position a $100 \mathrm{~Kb}$ sequence from position 19,094,276-19,194,275 was scanned for SSRs and four primer pairs (PN18-01-PN18-04) were designed based on these repeats. The PN18-01 primer pair (sense TGCTTGGCACCTTTTGCATACCTGCCTG, antisense CGAGAATATAGATGGGACTTTTTGGTAGGA) clearly 
Table 3 Non-parametric Kruskal-Wallis analysis of markers associated with QTLs for powdery mildew resistance of different tissue types

\begin{tabular}{|c|c|c|c|c|c|c|c|}
\hline \multirow[t]{2}{*}{ Trait } & \multirow[t]{2}{*}{ Chrom. } & \multirow[t]{2}{*}{ Markers } & \multicolumn{5}{|c|}{ Population and (progeny size) } \\
\hline & & & $06708(97)$ & $04327(47)$ & $06712(80)$ & $08391(255)$ & $08306(42)$ \\
\hline \multirow[t]{6}{*}{ Leaf } & 18 & $\mathrm{VMCNg} 2 \mathrm{f} 12$ & & & $* * * * * * *$ & $* * * * * *$ & $* * * * * * *$ \\
\hline & & VMCNg1e3 & & & $* * * * * * *$ & $* * * * * * *$ & - \\
\hline & & VVIn16 & & & $* * * * * * *$ & $* * * * * * *$ & - \\
\hline & & PN18-01 & & & - & - & $* * * * * * *$ \\
\hline & & VMC7f2 & & & $* * * * * * *$ & $* * * * * * *$ & $* * * * * * *$ \\
\hline & & UDV108 & & & $* * * * * * *$ & $* * * * * * *$ & $* * * * * * *$ \\
\hline \multirow[t]{11}{*}{ Cane } & 12 & $\operatorname{ctg} 1013230$ & & & & & $* * *$ \\
\hline & & UDV024 & & & & & $* * * *$ \\
\hline & & $\mathrm{VMC} 4 \mathrm{c} 10$ & & & & & $* * *$ \\
\hline & & VMC4f3.1 & & & & & $* *$ \\
\hline & 18 & $\mathrm{VMCNg} 2 \mathrm{f} 12$ & $* * * * * * *$ & & $* * * *$ & & \\
\hline & & VMCNg1e3 & $* * * * * * *$ & & $* * * *$ & & - \\
\hline & & VVIn16 & $* * * * * * *$ & $* *$ & $* * * *$ & & - \\
\hline & & VMC6f11 & $* * * * * *$ & - & - & & \\
\hline & & PN18-01 & $* * * * * *$ & - & - & & \\
\hline & & VMC7f2 & $* * * * * * *$ & & $* * * *$ & & \\
\hline & & UDV108 & $* *$ & & $* * * *$ & & \\
\hline \multirow[t]{7}{*}{ Rachis } & 18 & VMCNg2f12 & $* * * * * * *$ & & $* * * * * * *$ & & \\
\hline & & VMCNg1e3 & $* * * * * * *$ & $* *$ & $* * * * * * *$ & & \\
\hline & & VVIn16 & $* * * * * * *$ & $* * * *$ & $* * * * * * *$ & & \\
\hline & & VMC6f11 & $* * * * * *$ & - & - & & \\
\hline & & PN18-01 & $* * * * * *$ & - & - & & \\
\hline & & VMC7f2 & $* * * * * * *$ & $* * * *$ & $* * * * * * *$ & & \\
\hline & & UDV108 & $* * * *$ & $* * * *$ & $* * * * * * *$ & & \\
\hline \multirow[t]{4}{*}{ Fruit } & 18 & VMCNg1e3 & & $* *$ & $* * * * * * *$ & & \\
\hline & & VVIn16 & & $* * *$ & $* * * * * * *$ & & \\
\hline & & VMC7f2 & & $* * *$ & $* * * * * * *$ & & \\
\hline & & UDV108 & & $* *$ & $* * * * * * *$ & & \\
\hline
\end{tabular}

Marker order is consistent with the map for each group and population. Markers that were not polymorphic for certain populations are marked as missing “-”

$* * 0.05, * * * 0.01, * * * * 0.005, * * * * * 0.001, * * * * * * 0.0005, * * * * * * * 0.0001$

amplified and produced a banding pattern for all $V$. vinifera cultivars and $V$. romanetii, but did not amplify with any of the $M$. rotundifolia cultivars. The VR-hybrids (JB81-10711 and e2-9) showed only one allele coming from the $V$. vinifera parent. Considering the $M$. rotundifolia allele as "null", PN18-01 was scored in the 06708 population and it mapped between markers VMC6f11 and VMC7f2, reducing the genetic distance to $5.0 \mathrm{cM}$ (Suppl. Fig. 1). The previously published marker UDV305 was also used, but it did not produce a clear banding pattern for any of the parents (Bellin et al. 2009). Powdery mildew symptoms on all tissues were more pronounced in the 06712 population, and all five categories of symptom expression were observed. Overlapping QTLs were identified for resistance on all four tissues types on chromosome 18, which explained $12.6-52.8 \%$ of the phenotypic variation (Suppl.
Fig. 1). We named this locus "Run2.1". The name Run2 distinguishes it from the Runl locus that was previously mapped to chromosome 12 and "0.1" identifies the M. rotundifolia cultivar 'Magnolia' source (Pauquet et al. 2001). Table 2 provides the allelic profiles of markers linked to the resistance on chromosome 18 and on chromosome 12 to distinguish the inheritance of alleles from 'Magnolia' and JB81-107-11. A comparison of the alleles indicated that the resistant allele combination 193/202 with markers VMC7f2/UDV108, respectively, was not present in the complex hybrid parent 'Verdelet' but was present in the grandparent 'Magnolia' (Table 2). The cultivar 'Trayshed' has a very different allelic profile with these markers and it is likely that the UC Davis e4-12 accession did not inherit the 'Trayshed'-based powdery mildew resistance on chromosome 18 (Tables 1, 2). None of the accessions 
Table 4 Chromosome location of powdery mildew resistance on various tissues, and the significance and confidence intervals of QTLs identified by interval mapping in five grapevine populations

\begin{tabular}{|c|c|c|c|c|c|c|c|}
\hline Population & Trait & Chrom. & $\begin{array}{l}\text { Nearest } \\
\text { marker }\end{array}$ & $\begin{array}{l}\text { LOD } \\
\text { score }\end{array}$ & $\begin{array}{l}\text { LOD threshold } \\
\alpha=5 \% \text { on } \\
\text { the group } \\
\text { concerned }\end{array}$ & $\begin{array}{l}\text { Confidence } \\
\text { interval } \pm 1 \\
\text { LOD in CM }\end{array}$ & $\begin{array}{l}\text { Percentage of } \\
\text { total variance } \\
\text { explained } \\
\text { by the QTL }\end{array}$ \\
\hline \multirow[t]{3}{*}{06708} & Cane & 18 & VMC7f2 & 4.59 & 1.6 & $47.6-68.7$ & 20.4 \\
\hline & Rachis & 18 & VMCNg1e3 & 5.70 & 1.5 & $35.4-42.5$ & 27.4 \\
\hline & & 18 & VMC7f2 & 4.72 & 1.5 & $47.6-68.7$ & 23.3 \\
\hline \multirow[t]{2}{*}{04327} & Rachis & 18 & VVIn16 & 2.71 & 1.5 & $19.4-34.5$ & 31.3 \\
\hline & Fruit & 18 & VMC7f2 & 1.64 & 1.5 & $26.2-46.2$ & 19.6 \\
\hline \multirow[t]{4}{*}{06712} & Leaf & 18 & VMC7f2 & 12.55 & 1.2 & $6.80-9.35$ & 52.8 \\
\hline & Cane & 18 & VMC7f2 & 2.26 & 1.2 & $6.80-9.35$ & 12.6 \\
\hline & Rachis & 18 & VMC7f2 & 5.70 & 1.1 & $6.80-9.35$ & 33.2 \\
\hline & Fruit & 18 & VMC7f2 & 3.55 & 1.1 & $6.80-9.35$ & 22.5 \\
\hline 08391 & Leaf & 18 & VMC7f2 & 38.14 & 1.4 & $46.6-52.4$ & 50.0 \\
\hline 08306 & Leaf & 18 & VMC7f2 & 10.88 & 1.3 & $7.0-13.0$ & 69.7 \\
\hline
\end{tabular}

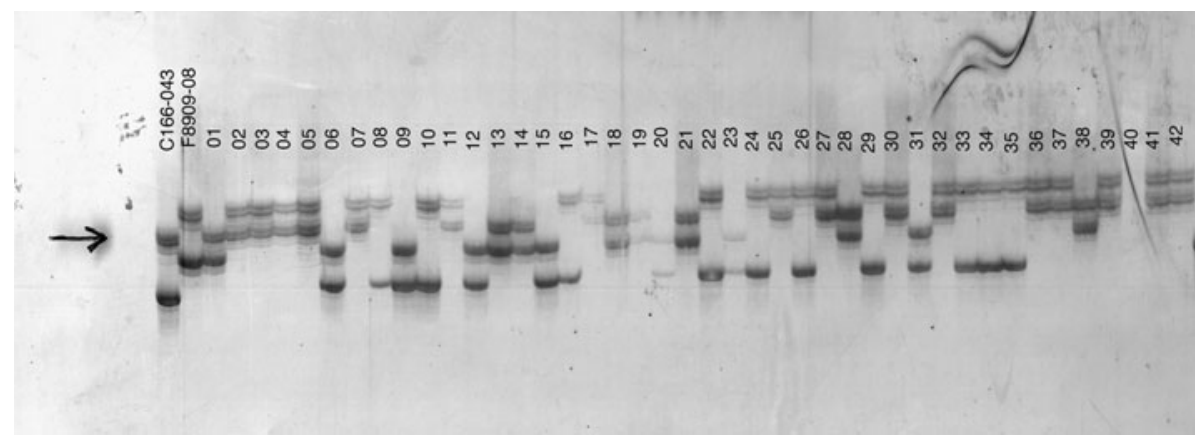

Fig. 3 Gel image of the PN18-01 marker assayed in the 08306 population whose powdery mildew resistance is derived from $V$. romanetii C166-043. The first two lanes consist of the resistant and susceptible parents followed by 42 progeny. The arrow marks the resistant allele from C166-043. Progeny with the resistant allele were devoid of powdery mildew symptoms on their leaves (except $F_{1}$ parents $F 2-35$ and 'Trayshed') in the background of UC Davis e4-12 exist any longer, which prevented the examination of their resistance alleles or response to powdery mildew.

In the JB81-107-11 background, QTL effects peaked at the VMC7f2 marker with LOD thresholds ranging from 2.26 to 12.55 for different tissue types (Table 4). The PN18-01 marker was not scored because the $V$. vinifera allele from A90-71 was similar in size to the susceptible $V$. vinifera parent. Due to the lack of a recombination event between VVIn16 and VMC7f2 as well as between VMCNg1e3 and VMCNg2f12, the distance between the VMCNg1e3 and UDV108 markers in the 06712 population was shorter, $2.56 \mathrm{cM}$, when compared to the $31 \mathrm{cM}$ distance between these markers in the 06708 population (Suppl. Fig. 1). This also explains the co-localization of QTLs for all tissue types in one region only around VMC7f2, as compared to the two genomic regions observed in the $\mathrm{BC}_{1}$ populations 06708 and 04327.
Only leaf symptoms were scored in the 08391 population and a major locus was identified on chromosome 18 at a LOD threshold of 38.14 and explaining $50.0 \%$ of the phenotypic variation (Table 4, Suppl. Fig. 1). This locus inherited from 'Trayshed' was named "Run2.2" to distinguish it from the Run2.1 locus inherited from 'Magnolia'. Run2.2 was in the same genomic region identified in the three other populations possessing JB81-107-11 parentage.

The PN18-01 marker was not useful in the 08391 population due to the similar allele sizes of the $V$. vinifera parents, however, PN18-01 was fully informative for the 08306 population and the resistance allele from $\mathrm{V}$. romanetii co-segregated with leaf powdery mildew resistance (Fig. 3). A major locus for leaf resistance was identified on chromosome 18, which explained up to $70.0 \%$ of the phenotypic variation at a LOD threshold of 10.88 (Tables 3, 4; Suppl. Fig. 1). Previous reports of powdery mildew resistance from a non- $M$. rotundifolia-based Vitis species named the locus Renl and it mapped on 
Table 5 Ordinal logistic model results for powdery mildew resistance (leaf, stem rachis, and berry) evaluations in the field versus genetic marker

\begin{tabular}{llllllll}
\hline Population & $\begin{array}{l}\text { No. of genotypes } \\
\text { used for analysis }\end{array}$ & Whole model $P$ value & Chromosome 12 & Chromosome 13 & $\begin{array}{c}\text { Chromosome 18 } \\
\text { Chromosome } \\
12 \times 18\end{array}$ & $\begin{array}{l}\text { Chromosome } \\
13 x L G 18\end{array}$ \\
\hline 04327 & 26 & $0.0226^{*}$ & 0.6257 & - & $0.0031^{*}$ & 0.221 \\
06708 & 54 & $0.0005^{*}$ & 0.4914 & - & $<0.0001^{*}$ & 0.5705 & - \\
06712 & 41 & $<0.0001^{*}$ & 0.9326 & - & $<0.0001^{*}$ & 0.4851 & - \\
08391 & 238 & $<0.0001^{*}$ & - & - & $<0.0001^{*}$ & - & - \\
08306 & 32 & $<0.0001^{*}$ & 0.3126 & 0.4961 & $0.0023^{*}$ & 0.5711 & 0.4554 \\
\hline
\end{tabular}

Values marked by asterisks are significant

chromosome 13 (Hoffman et al. 2008; Coleman et al. 2009). The major locus for powdery mildew resistance in $V$. romanetii was named 'Ren4' to distinguish it from Ren1. Stem powdery mildew resistance in the 08306 population was linked to markers from chromosome 12 with a significant association at $P=0.005$, but QTLs for stem resistance were not identified with the SIM method (Table 3).

When the association of mildew resistance across all four tissues was evaluated with the ordinal logistic regression model the interaction was only highly significant for chromosome 18 across all five populations (Table 5). No significant interaction of chromosome 18 to the other evaluated chromosomes was observed in any of the five tested populations.

\section{Discussion}

In this study, we utilized a limited mapping strategy in conjunction with field evaluation data for powdery mildew resistance in different sized breeding populations with resistance from three different backgrounds. We identified a major locus, Ren4, for powdery mildew resistance in the Chinese species, $V$. romanetii, and two resistance loci, Run2.1 and Run2.2, from two different $M$. rotundifolia cultivars ('Trayshed' and 'Magnolia') on chromosome 18. The identification of an overlapping resistance region from three different genetic backgrounds is of significant importance to grape breeders, as well as to molecular biologists studying host-pathogen interactions, the evolution of resistance mechanisms, and comparative analysis of key resistance genes. The region of chromosome 18 where powdery mildew resistance resides has also been found to be coupled with downy mildew resistance loci: $R p v 2$ from the $M$. rotundifolia cultivar 'Trayshed'; and Rpv3 from two different populations in which downy mildew resistance is inherited from North American Vitis species (Merdinoglu et al. 2003; Fischer et al. 2004; Welter et al. 2007; Bellin et al. 2009). The downy mildew resistance locus, $R p v 1$, on chromosome 12 is also tightly coupled with the powdery mildew resistance locus, Runl (Dry et al. 2009). Therefore, it was not surprising to find overlapping powdery and downy mildew resistance regions from different genetic backgrounds on chromosome 18. This finding also validates the use of a limited mapping strategy to examine new powdery mildew resistance sources, instead of developing a complete map of all 19 grape chromosomes.

Powdery and downy mildew are biotrophic obligate parasites that originated in North America and coevolved with North American Vitis and Muscadinia species in their native range. Resistance to both diseases is known to be controlled by resistance genes in the NBS-LRR category. This large class of resistance genes (R-genes) are present in clusters and provide a reservoir of genetic variation to facilitate adaptation to rapidly evolving pathogens via gene duplication, unequal crossing-over and diversifying selection (Michelmore and Meyers 1998). Di Gaspero et al. (2007) mapped 82 RGA-like markers and the majority of these were on chromosome 18. In a recent article from Zyprian et al. (2009), powdery mildew resistance from Villard blanc, Regent and Börner mapped to chromosome 18 in close association with RGA marker rgVamu137. Other studies have reported mapping of powdery mildew resistance on chromosome 12, 13, and 15, and downy mildew resistance on chromosome 4, 7, 9, 12, 15, and 18; chromosomes that are rich with different classes of R-genes families (Pauquet et al. 2001; Merdinoglu et al. 2003; Fischer et al. 2004; Welter et al. 2007; Hoffmann et al. 2008; Marguerit et al. 2009; Bellin et al. 2009). In particular, chromosome 18 contains large clusters of the TIR-NBS-LRR category of genes and surpasses all other chromosomes for the number of resistance genes (Velasco et al. 2007; Moroldo et al. 2008; Yang et al. 2008). Only sequence comparisons of chromosome 18 among diverse resistant backgrounds can reveal the architecture and number of resistance genes involved in the plant-pathogen interaction. In this study, the two cultivars of $M$. rotundifolia used to map powdery mildew resistance had different alleles for the SSR markers associated with resistance (UDV108 and VMC7f2), and did not have common alleles (Table 2). The lack of a priming site for the newly 
developed SSR marker PN18-01 in M. rotundifolia exemplifies the sequence divergence between Muscadinia and Vitis grape species. In contrast, PN18-01 amplified successfully in $V$. romanetii, and also had a very different allelic composition compared to the M. rotundifolia cultivars for all other markers where genomic DNA amplified (Table 2).

The QTL regions associated with resistance on different tissues overlapped in three of the populations based on JB81-107-11, even though the level of resistance observed on the leaf, stem, rachis, and berry did not correlate with each other and seemed to segregate independently. In some cases, field observations detected powdery mildew symptoms on leaves and petioles, but the stems, berries, and rachis were free of symptoms. Conversely, symptoms were detected on berries and the rachis, but not on the stems and leaves. There are no previous reports of observations of similar inverse relationships; however, (Kennelly et al. 2005a, b) reported downy mildew symptoms on berries while the foliage of 'Chancellor' was symptom-free. They also observed symptoms on the foliage of 'Delaware' while the clusters were unaffected. In another downy mildew study, Welter et al. (2007) detected overlapping QTLs for leaf and berry resistance on chromosome 18 from 'Regent'. The overlapping of resistance QTLs for different tissue types that we observed might be an artifact due to small population sizes as well as relatively low-resolution maps. Nonetheless, these maps provide the framework for more focussed research, which will require increasing the population sizes and the number of markers for a targeted region on chromosome 18 .

The population sizes varied among different genetic backgrounds, from 42 seedlings in the 08306 population to 255 seedlings in the 08391 population. The size of studied population is important for QTL studies. Limited population size leads to under estimation of QTL numbers, over estimation of effects and failure to quantify QTL interactions. Vales et al. (2005) studied the effect of population size on the estimation of QTL for barley stripe rust resistance and came to the conclusion that QTLs with large effect could be detected with relatively small populations, but it was necessary to increase the population size to detect QTLs of small effects. In this study, a major locus in the 08306 population that explains up to $70 \%$ of the phenotypic variation was detected (Table 4). QTLs linked to resistance on different tissues with large effects in overlapping regions were also identified in three populations with JB81-107-11 in their parentage, including a major locus in the 08391 population explaining up to $50 \%$ of the phenotypic variation (Table 4). These results are very promising from a grape breeder's perspective, as they could utilize smaller population sizes and this targeted, limited mapping approach in conjunction with field evaluations to scan additional germplasm resources is a cost effective method. In addition to the overlapping regions and inconsistent symptom expression on different tissues, the genetic distance between flanking markers associated with the powdery resistance of different tissue types varied greatly from the $\mathrm{BC}_{2}$ to the $\mathrm{BC}_{3}$ generation (26.8-30.0 to $3.0-7.0 \mathrm{cM}$ ). Increasing the population size and map density as well as multiple years of field evaluation data would likely fine-tune the identity of the exact genomic region associated with the resistance of different tissue types. It is also possible that multiple genes from a wider genetic area are involved, and that combinations of genes or different alleles of same gene provide strain specific resistance. The downy mildew resistance of North American grape species is reported to be strain specific (Cadle-Davidson 2008) and it is possible that same situation exists for powdery mildew resistance.

The severity of powdery mildew pressure could vary from year to year due to a varying composition of strains, and strain composition could vary within an experimental plot. Montarry et al. (2008) reported a strong relationship between disease severity and the genetic composition of E. necator populations. Given grape's well-described genome-wide heterozygosity and the resulting variable physiological and morphological characteristics in seedling populations, the magnitude and nature of disease symptoms would be expected to vary, further adding to the complexity of evaluating powdery mildew resistance. Based on field observations in the three $M$. rotundifolia 'Magnolia'based populations, it seems unlikely that a single gene could confer resistance to all tissue types. Another confounding factor is that the tolerance level of $V$. vinifera cultivars to powdery mildew also varies (Roy and Ramming 1990). Some varieties are very susceptible (ex. 'Carignane' and 'Ruby Seedless') while others are tolerant (ex. 'Barbera' and 'Pinot noir'), suggesting that $V$. vinifera carries resistance genes that only function when confronted by less aggressive powdery mildew strains, or that only provide partial resistance. We have observed that the selection of $V$. vinifera parents has a large impact on the ratio of resistant to susceptible genotypes in wine and table grape breeding populations (unpublished data).

Powdery mildew resistance is reported to vary in different cultivars of $M$. rotundifolia across its native range in the southern US (Carroll et al. 1991), suggesting that powdery mildew has the capacity to respond rapidly to host-based selection pressure and generate isolates that can overcome $M$. rotundifolia's resistance. 'Magnolia' is reported to be susceptible in North Carolina (Carroll et al. 1991), but it has never shown symptoms in California (unpublished data). No field or greenhouse data on the resistance of 'Trayshed' is available outside of California. Based on historical records and the relative resistance of 
North American Vitis species to powdery mildew, E. necator has been considered to be native to the eastern United States and introduced into all other grape-growing regions of the world (Brewer and Milgroom 2008). Sequence data in combination with morphological, host, and paleontological information provide powerful approaches to the study of origins and spread of pathogens, and the co-evolution of host-pathogen relationships (Matsuda and Takamatsu 2003). Studies on the genetic variation of E. necator in Europe and Australia have found only two distinct genetic groups or lineages, termed A and B. Péros et al. (2005) reported that powdery mildew strains in Europe and Australia are quite homogeneous and that the diversity found in E. necator populations is lower than what exists in North American strains. Brewer and Milgroom (2008) studied sequence diversity and genetic lineages of E. necator in North America, Europe, and Australia and found that populations in the eastern US are much more diverse than in Europe and Australia. They also found that the isolates present in California belong to group B, the same as found in Europe and Australia. Many Chinese Vitis species are resistant to powdery and downy mildew, including $V$. romanetii (Wan et al. 2007). The existence of powdery and downy mildew resistance in Chinese species does not fit the model of host-pathogen co-evolution, given that these mildews evolved with North American Vitis species. It is possible that powdery and downy mildew historically existed in China, one of the principle centers of origin of Vitis species. This seems necessary given that R-gene-mediated resistance is the result of a significant period of co-evolution between host and pathogen. A survey of Chinese powdery mildew strains and comparison of their sequences with strains through out the world is needed to test this hypothesis.

The mechanism of the observed resistance in V. romanetii, and both $M$. rotundifolia cultivars is currently under investigation using leaf disk assays. It seems likely that this resistance is due to a hypersensitive response given the observed arrested fungal growth and necrotic spotting on leaves, stems, rachis, and berries. Considering the variation in virulence of powdery mildew strains from different geographical regions, it is very important for grape breeders to pyramid different resistance sources into single lines to develop durable field resistance. To date, two resistance mechanisms have been reported for powdery mildew. The first is the Runl-mediated resistance that involves the induction of programed cell death within the invaded epidermal cell, $24-48 \mathrm{~h}$ after infection. The second is Ren1-mediated resistance, which allows the formation of a germ tube and the establishment of an appressorium, but suppressed hyphal development and conidiophore production (Hoffman et al. 2008; Dry et al. 2009). These resistance gene(s) are on different chromosomes, making it possible to pyramid resistance via marker-assisted selection (Eibach et al. 2007; Molnár et al. 2007).

This study's identification and mapping of powdery mildew resistance on chromosome 18 from three different resistance sources advances the powdery mildew resistance breeding effort. Given the time required to introgress resistance from wild species into an elite cultivated background, efforts to complex multiple forms of resistance early in the breeding process should be taken. The identification of an apparently single gene form of powdery mildew resistance from $V$. romanetii is very important for grape breeders given its neutral fruit flavor and breeding compatibility with $V$. vinifera cultivars, particularly when compared to $M$. rotundifolia. Findings from this study also pose more questions, e.g., is the $M$. rotundifolia-based resistance controlled by the Runl locus on chromosome 12 the same as that controlled by Run 2 on chromosome 18; are these different or duplicated resistance genes? Are the resistance genes in $V$. romanetii similar to those in $M$. rotundifolia? Is it possible that $V$. romanetii carries downy mildew resistance in the same region where powdery mildew resistance has been mapped? If both resistances are present in $V$. romanetii, it would further expand its breeding value.

Acknowledgments Research funding from the American Vineyard Foundation, Viticulture Consortium West and the Louis P. Martini Endowed Chair funds is gratefully acknowledged. The authors are also grateful to Dr. Jeff Bloodworth for use of JB81-107-11.

Open Access This article is distributed under the terms of the Creative Commons Attribution Noncommercial License which permits any noncommercial use, distribution, and reproduction in any medium, provided the original author(s) and source are credited.

\section{References}

Akkurt M, Welter L, Maul E, Reinhard T, Zyprian E (2006) Development of scar markers linked to powdery mildew (Uncinula necator) resistance in grapevine (Vitis vinifera $\mathrm{L}$. and Vitis sp). Mol Breed 19:103-111

Barker CL, Donald T, Pauquet J, Ratnaparkhe MB, Bouquet A, Adam-Blondon A-F, Thomas MR, Dry I (2005) Genetic and physical mapping of the grape powdery mildew resistance gene, Run1, using a bacterial artificial chromosome library. Theor Appl Genet 111:370-377

Bellin D, Peressotti E, Merdinoglu D, Wiedemann-Merdinoglu S, Adam-Blondon A-F, Cipriani G, Morgante M, Testolin R, Di Gaspero G (2009) Resistance to Plasmopara viticola in grapevine 'Bianca' is controlled by a major dominant gene causing localized necrosis at the infection site. Theor Appl Genet 120: 163-176

Brewer MT, Milgroom MG (2008) Phylogeography and sequence diversity of genetic lineages of the grapevine powdery mildew fungus, Erysiphe (Uncinula) necator, in North America, Europe, and Australia. Phytopathology 98:S25-S26 (abstract) 
Cabezas JA, Cervera MT, Ruiz-Garcia L, Carreño J, MartínezZapater JM (2006) A genetic analysis of seed and berry weight in grapevine. Genome 49:1572-1585

Cadle-Davidson L (2008) Variation within and between Vitis spp. for foliar resistance to the downy mildew pathogen Plasmopara viticola. Plant Dis 92:1577-1584

Carroll DE, Poling EB, Goldy RG (1991) Wine-grape reference for North Carolina. Bulletin 480, The North Carolina Agricultural Research Service

Cipriani G, Marrazzo MT, Di Gaspero G, Pfeiffer A, Morgante M, Testolin R (2008) A set of microsatellite markers with long core repeat optimized for grape (Vitis spp.) genotyping. BMC Plant Biol 8:127

Coleman C, Copetti D, Cipriani G, Hoffmann S, Kozma P, Kovacs L, Morgante M, Testolin R, Di Gaspero G (2009) The powdery mildew resistance gene REN1 cosegregates with an NBS-LRR gene cluster in two central Asian grape varieties. BMC Genet 10:89

Dalbo MA, Ye G-N, Weeden NF, Wilcox WF, Reisch BI (2001) Marker-assisted selection for powdery mildew resistance in grapes. J Am Soc Hortic Sci 126:83-89

Di Gaspero G, Cipriani G, Marrazzo MT, Andreetta D, Prado Castro MJ, Peterlunger E, Testolin R (2005) Isolation of (AC)nmicrosatellites in Vitis vinifera $\mathrm{L}$. and analysis of genetic background in grapevines under marker assisted selection. Mol Breed 15:11-20

Di Gaspero G, Cipriani G, Adam-Blondon AF, Testolin R (2007) Linkage maps of grapevine dis-playing the chromosomal locations of 420 microsatellite markers and 82 markers for R-gene candidates. Theor Appl Genet 114:1249-1263

Dick MW (2002) Towards an understanding of the evolution of the downy mildews. In:Spencer-Phillips PTN, Gisi U, Lebeda A (eds) Advances in downy mildew research, vol 1. Kluwer, Dordrecht, pp 1-59

Doligez A, Adam-Blondon A-F, Cipriani G, Di Gaspero G, Laucou V, Merdinoglu D, Meredith CP, Riaz S, Roux C, This P (2006) An integrated SSR map of grapevine based on five different populations. Theor Appl Genet 113:369-382

Dry IB, Feechan A, Anderson C, Jermakow AM, Bouquet A, AdamBlondon A-F, Thomas MR (2009) Molecular strategies to enhance the genetic resistance of grapevines to powdery mildew. Aust J Grape Wine Res 16:94-105

Eibach R, Diehl H, Alleweldt G (1989) Untersuchungen zur Vererbung von Resistenzeigenschaften bei Reben gegen Oidium tuckeri, Plasmopara viticola und Botrytis cinerea. Vitis 28:209-228

Eibach R, Zyprian E, Welter L, Töpfer R (2007) The use of molecular markers for pyramiding resistance genes in grapevine breeding. Vitis 46:120-140

Falconer DS, Mackay TFC (1996) Introduction to quantitative genetics, 4th edn. Longman, Harlow

Fischer BM, Salakhutdinov I, Akkurt M, Eibach R, Edwards KJ, Töpfer R, Zyprian EM (2004) Quantitative trait locus analysis of fungal disease resistance factors on a molecular map of grapevine. Theor Appl Genet 108:501-515

Hoffmann S, Di Gaspero G, Kovacs L, Howard S, Kiss E, Galbacs Z, Testolin R, Kozma P (2008) Resistance to Erysiphe necator in the grapevine 'Kishmish vatkana' is controlled by a single locus through restriction of hyphal growth. Theor Appl Genet 116: $427-438$

Jaillon O, Aury JM, Noel B, Policriti A, Clepet C, Casagrande A, Choisne N, Aubourg S, Vitulo N, Jubin C, Vezzi A, Legeai F, Hugueney P, Dasilva C, Horner D, Mica E, Jublot D, Poulain J, Bruyere C, Billault A, Segurens B, Gouyvenoux M, Ugarte E, Cattonaro F, Anthouard V, Vico V, Del Fabbro C, Alaux M, Di Gaspero G, Dumas V, Felice N, Paillard S, Juman I, Moroldo M, Scalabrin S, Canaguier A, Le Clainche I, Malacrida G, Durand
E, Pesole G, Laucou V, Chatelet P, Merdinoglu D, Delledonne M, Pezzotti M, Lecharny A, Scarpelli C, Artiguenave F, Pe ME, Valle G, Morgante M, Caboche M, Adam-Blondon AF, Weissenbach J, Quetier F, Wincker P (2007) The grapevine genome sequence suggests ancestral hexaploidization in major angiosperm phyla. Nature 2007(449):463-467

Kennelly MM, Eugster C, Gadoury DM, Smart CD, Seem RC, Gobbin D, Gessler C (2005a) Contributions of oospore inoculum to epidemics of grapevine downy mildew (Plasmopara viticola). Phytopathology 94:S50

Kennelly MM, Gadoury DM, Wilcox WF, Magarey PA, Seem RC (2005b) Seasonal development of ontogenic resistance to downy mildew in grape berries and rachises. Phytopathology 95:1445-1452

Kosambi DD (1944) The estimation of map distances from recombination values. Ann Eugen 12:172-175

Lander ES, Botstein D (1989) Mapping Mendelian factors underlying quantitative traits using RFLP linkage maps. Genetics 121: 185-199

Lodhi MA, Reisch BI, Weeden NF (1994) A simple and efficient method for DNA extraction from grapevine cultivars and Vitis species. Plant Mol Biol Rep 12:6-13

Marguerit E, Boury C, Manicki A, Donnart M, Butterlin G, Némorin A, Wiedemann-Merdinoglu S, Merdinoglu D, Ollat N, Decroocq $S$ (2009) Genetic dissection of sex determinism, inflorescence morphology and downy mildew resistance in grapevine. Theor Appl Genet 118:1261-1278

Matsuda S, Takamatsu S (2003) Evolution of host-parasite relationship of Golovinomyces (Ascomycete: Erysiphales) inferred from nuclear rDNA sequences. Mol Phylogenet Evol 27:314-327

Mejía N, Gebauer M, Muñoz L, Hewstone N, Hinrichsen P (2007) Identification of QTLs for seedlessness, berry size, and ripening date in a seedless $\times$ seedless table grape progeny. Am J Enol Vitic 58:499-507

Merdinoglu D, Wiedemann-Merdinoglu S, Coste P, Dumas V, Haetty S, Butterlin G, Greif C (2003) Genetic analysis of downy mildew resistance derived from Muscadinia rotundifolia. Acta Hortic 603:451-456

Merdinoglu D, Butterlin G, Bevilacqua L, Chiquet V, Adam-Blondon AF, Decroocq S (2005) Development and characterization of a large set of microsatellite markers in grapevine (Vitis vinifera L.) suitable for multiplex PCR. Mol Breed 15:349-366

Michelmore RW, Meyers BC (1998) Clusters of resistance genes in plants evolve by divergent selection and a birth-and-death process. Genome Res 8:1113-1130

Miller TC, Gubler WD (2004) Sensitivity of California isolates of Uncinula necator to trifloxystrobin and spiroxamine, and update on triadimefon sensitivity. Plant Dis 88:1205-1212

Molnár S, Galbács Z, Halász G, Hoffmann S, Kiss E, Kozma P, Veres A, Galli Z, Szöke A, Heszky L (2007) Marker assisted selection (MAS) for powdery mildew resistance in a grapevine hybrid family. Vitis 46:212-213

Montarry J, Cartolaro P, Delmotte F, Jolivet J, Willocquet L (2008) Genetic structure and aggressiveness of Erysiphe necator populations during grapevine powdery mildew epidemics. Appl Environ Microbiol 74:6327-6332

Moroldo M, Paillard S, Marconi R, Fabrice L, Canaguier A, Cruaud C, De Berardinis V, Guichard C, Brunaud V, Le Clainche I, Scalabrin S, Testolin R, Di Gaspero G, Morgante M, AdamBlondon AF (2008) A physical map of the heterozygous grapevine 'Cabernet Sauvignon' allows mapping candidate genes for disease resistance. BMC Plant Biol 8:38

Olmo HP (1986) The potential role of (vinifera $\times$ rotundifolia) hybrids in grape variety improvement. Experientia 42:921-926

Organisation Internationale de la Vigne et du Vin (OIV) (1984) Codes des caractères descriptifs des variétés et espèces de Vitis. OIV, Paris 
Pauquet J, Bouquet A, This P, Adam-Blondon A-F (2001) Establishment of a local map of AFLP markers around the powdery mildew resistance gene Run1 in grapevine and assessment of their usefulness for marker aided selection. Theor Appl Genet 103:1201-1210

Péros JP, Troulet C, Guerriero M, Michel-Romiti C, Notteghem JL (2005) Genetic variation and population structure of the grape powdery mildew fungus, Erysiphe necator, in southern France. Eur J Plant Pathol 113:407-416

Riaz S, Dangl GS, Edwards KJ, Meredith CP (2004) A microsatellite marker based framework linkage map of Vitis vinifera L. Theor Appl Genet 108:864-872

Riaz S, Krivanek AF, Xu K, Walker MA (2006) Refined mapping of the Pierce's disease resistance locus, PdRl, and Sex on an extended genetic map of Vitis rupestris $\times V$. arizonica. Theor Appl Genet 113:1317-1329

Riaz S, Tenscher AC, Graziani R, Krivanek AF, Walker MA (2009) Using marker assisted selection to breed for Pierce's disease resistance in grapevine. Am J Enol Viticult 60:199-206

Roy RR, Ramming DW (1990) Varietal resistance of grape to the powdery mildew fungus, Uncinula necator. Fruit Var J 44:149-155

Staudt G (1997) Evaluation of resistance to grapevine powdery mildew (Uncinula necator) in accessions of Vitis species. Vitis 36:151-154

Vales MI, Schön CC, Capettini F, Chen XM, Corey AE, Mather DE, Mundt CC, Richardson KL, Sandoval-Islas JS, Utz HF, Hayes PM (2005) Effect of population size on the estimation of QTL: a test using resistance to barley stripe rust. Theor Appl Genet 111:1260-1270

Van Ooijen J, Boer M, Jansen R, Maliepaard C (2002) MapQTL ${ }^{\circledR} 4.0$ Software for the calculation of QTL positions on genetic maps. Plant Research International, Wageningen
Velasco R, Zharkikh A, Troggio M, Cartwright DA, Cestaro A, Pruss D, Pindo M, Fitzgerald LM, Vezzulli S, Reid J, Malacarne G, Iliev D, Coppola G, Wardell B, Micheletti D, Macalma T, Facci M, Mitchell JT, Perazzolli M, Eldredge G, Gatto P, Oyzerski R, Moretto M, Gutin N, Stefanini M, Chen Y, Segala C, Davenport C, Demattè L, Mraz A, Battilana J, Stormo K, Costa F, Tao Q, Si-Ammour A, Harkins T, Lackey A, Perbost C, Taillon B, Stella A, Solovyev V, Fawcett JA, Sterck L, Vandepoele K, Grando MS, Toppo S, Moser C, Lanchbury J, Bogden R, Skolnick M, Sgaramella V, Bhatnagar SK, Fontana P, Gutin A, Van de Peer Y, Salamini F, Viola R (2007) A high quality draft consensus sequence of the genome of a heterozygous grapevine variety. PLoS ONE 2:e1326

Walker AR, Lee E, Bogs J, McDavid DA, Thomas MR, Robinson SP (2007) White grapes arose through the mutation of two similar and adjacent regulatory genes. Plant J 49:772-785

Wan Y, Schwaniniger H, He P, Wang Y (2007) Comparison of resistance to powdery mildew and downy mildew in Chinese wild grapes. Vitis 46:132-136

Welter LJ, Gokturk-Baydar N, Akkurt M, Maul E, Eibach R, Reinhard T, Zyprian EM (2007) Genetic mapping and localization of quantitative trait loci affecting fungal disease resistance and leaf morphology in grapevine (Vitis vinifera L.). Mol Breed 20:359-374

Xu K, Riaz S, Roncoroni NC, Jin Y, Hu R, Zhou R, Walker MA (2008) Genetic and QTL analysis of resistance to Xiphinema index in a grapevine cross. Theor Appl Genet 116:305-311

Yang S, Zhang X, Yue J-X, Tian D, Chen J-Q (2008) Recent duplications dominate NBS-encoding gene expansion in two woody species. Mol Genet Genomics 280:187-198

Zyprian E, Welter LJ, Akkurt M, Ebert S, Salakhutdinov I, GöktürkBaydar N, Eibach R, Töpfer R (2009) Genetic analysis of fungal disease resistance in grapevine. Acta Hort 827:535-538 